\title{
FÉKEK ÉS ÖSZTÖNZŐK A RADIKÁLIS ÚJITÁSOKBAN'
}

\section{BARRIERS AND INCENTIVES OF DISRUPTIVE INNOVATION}

\author{
Bartha Zoltán ${ }^{a}$, S. Gubik Andrea ${ }^{a}$ \\ aphD, egyetemi docens, Miskolci Egyetem \\ bartha.zoltan@ekon.me \\ getgubik@uni-miskolc.hu
}

\begin{abstract}
ÖSSZEFOGLALÁS
Napjaink korszelleme forradalmi változások rövid időn belül való bekövetkezését vetíti előre, ami a várakozások szerint egy emberöltőn belül felforgatja a világunkat, annak minden gazdasági, társadalmi és technológiai összetevőjével együtt. E várakozást a műszaki és egészségtudományi területeken megfigyelhető gyors fejlődésre szokás alapozni. Tanulmányunkban azt tekintjük át, hogy a technológiai lehetőségek és a gyakorlatban megvalósuló fejlesztések között kapcsolatot teremtő innovációs folyamat milyen jellemzőkkel bír, és melyek azok a befolyásolók, amelyek képesek ezt a folyamatot lassítani, illetve eltéríteni. A potenciális befolyásolókat egy egységes modellbe, az ún. innovációs burokba foglaltuk. E burok elemei a vállalati magba tömörített tulajdonosi érdek és menedzseri motiváció, a vállalati kultúra és a szervezeti felépítés, valamint az emberek; az innovációs ökoszisztéma részei, mégpedig a kutatási és finanszírozási infrastruktúra, illetve a szabályozórendszer; végül pedig a fogyasztók és érintettek értékei. Ezen összetevők között nemcsak ösztönzőket, hanem jó néhány féket is azonosíthatunk, és tanulmányunk elsősorban ezekre fókuszál.
\end{abstract}

\section{ABSTRACT}

The zeitgeist of today expects robust changes happening on the macro scale in the near future. These changes are expected to completely reshape the world around us, including its economic, social and technological environment. The main argument for the reshaping environment is based on the quick advances in areas like technology and health sciences. In our study we investigate the characteristics of the innovation process that creates the bridge between technological/theoretical possibilities, and practical innovations. We detect the main influencers that form the so called innovation shell. The innovation shell has three components: the corporate core (made up of ownership interests, managerial motivations, corporate culture and structure,

${ }^{1}$ A tanulmány Bartha Zoltán, S. Gubik Andrea (2018): „Technológiai változások - társadalmi fékek és ösztönzők" című könyvfejezetének rövidített és átdolgozott változata. In: Nováky E. - S. Gubik A. (szerk.): A múltból átívelö jövö - VIII. Magyar (Jubileumi) Jövőkutatási Konferencia. 50 éves a magyar jövőkutatás, 2018. Budapest, 2018. november 14-25. Konferenciakötet. Györ: Palatia Kiadó és Nyomda, 217-226. 
and people); the innovation ecosystem (made up of research and financial infrastructure, and regulating institutions); and finally the values of customers and stakeholders. Some of these influencers create barriers, others create incentives for innovation. In this study we focus on the former ones.

Kulcsszavak: innováció, intézmények, kutatás és fejlesztés, technológiai változás

Keywords: innovation, institutions, research and development, technological change

\section{BEVEZETÉS}

„Ezer évvel ezelőtt, 1018-ban, nagyon sok ismeretlen volt a jövővel kapcsolatban, de abban biztosak lehettek az akkor élők, hogy a társadalom alapvető építőkövei nem változnak meg. [...] Ezzel szemben napjainkban fogalmunk sincs, hogyan fog [...] a világ [...] kinézni 2050-ben. Nem tudjuk, miből fognak megélni az emberek, nem tudjuk, hogyan müködik majd az államigazgatás és a hadsereg, fogalmunk sincs, milyen lesz a nemek közötti kapcsolat" (Harari, 2018, 264.). Ez az idézet jól jellemzi a jövővel kapcsolatos várakozásainkat jelenleg meghatározó korszellemet. Azok közül, akik egy kicsit is érzékenyek a jövővel kapcsolatos kérdésekre, szinte mindenki úgy érzi, hogy olyan forradalmi átalakulások korát éljük, amelyek alapvetően forgatják fel a társadalmunkat.

Az a képzet, hogy a minket körbevevő világ egyre gyorsabban változik, nem új keletủ. A friss élmények mindig sokkal meghatározóbbak, amint arra a Daniel Kahneman és Amos Tversky által kimutatott reprezentativitási előítélet (Thaler, 2016) is felhívja a figyelmet. Szubjektív érzetünk szerint a jelenlegi változások igazán mély hatásúak és gyorsak, de meglehet, ez csak azért van, mert a régebbi változásokra már egyáltalán nem emlékszünk. Amint Jeremy Greenwood és szerzőtársai kimutatták (2005), a különbözö háztartási gépeknek köszönhetően 1900 és 1975 között a hetente átlagosan a házimunkára fordított órák száma 58ról 18-ra csökkent, amit bátran nevezhetünk forradalminak, a mostani generációk emlékeiben viszont ebből alig él valami. Sokkal élénkebb a fantáziánk, ha a jövőre kell gondolnunk: 1972 óta már több felmérésen kérdezték meg a szakértőket az emberi szintủ mesterséges intelligencia kifejlesztésének várható időszükségletéről, és a válaszok mediánja azóta is stabilan ötven év körül alakul (Bartha-Gubik, 2018). Amikor a technológiai lehetőségeket nézzük, fantáziánk könnyen szárnyra kelhet, és hajlamosak vagyunk megfeledkezni arról, hogy a technológia fejlődésének irányát a társadalom olyan szeletei is meghatározzák, amelyek csak nagyon nehezen és nagyon lassan változnak.

Bár a forradalmi változások alapgondolatával nem kívánunk vitatkozni, ebben a tanulmányban azokra a társadalmi befolyásolókra fókuszálunk, amelyek lassít- 
hatják és eltéríthetik a technikai fejlődés irányát, ezen keresztül pedig alapvetően hatnak a ránk váró jövőre. Ezek a társadalmi befolyásolók ún. intézményi tényezők, amelyekre egyrészt az jellemző, hogy lassan változnak, másrészt viszont alakulásukra a közösségnek hatása lehet a társadalmi vitákon és a politikai rendszeren keresztül.

\section{LEHETŐSÉGEK ÉS LEKÉPEZŐDÉSEK}

A technikai lehetőségek megvalósulása, valóságban való leképeződése az intézmények által lehatárolt. Az intézmények hatása kiterjedhet az új ötletek megszületésére, túlélési esélyeire és gyakorlati elterjedésére egyaránt. Ezeket a lépéseket az innovációs folyamattal írja le a közgazdaságtan, aminek egyik hagyományos, lineáris megközelítése, amit gyakran Joseph Schumpeter nevéhez is kötnek, a feltalálás, innováció és diffúzió hármasságára épül (Stoneman, 1995). E hármas egyes elemei, bár egymásra épülnek, időben jelentősen elválhatnak egymástól (lásd például az üzemanyagcellák esetét, amit továbbra is napjaink ígéretes technológiájának tartanak). Vitathatatlan, hogy az új technológiák lassú elterjedésének mérnöki-müszaki okai is vannak, de az elterjedés sebességére hatással vannak még olyan társadalmi-gazdasági tényezők is, amilyeneket az 1. ábrán bemutatott innovációs burok foglal össze számunkra. Az innovációs burok az irodalomban általában akadályozóként említett tényezőket tartalmazza: költség, tudás, piaci, intézményi és egyéb korlátok (OECD, 2005).

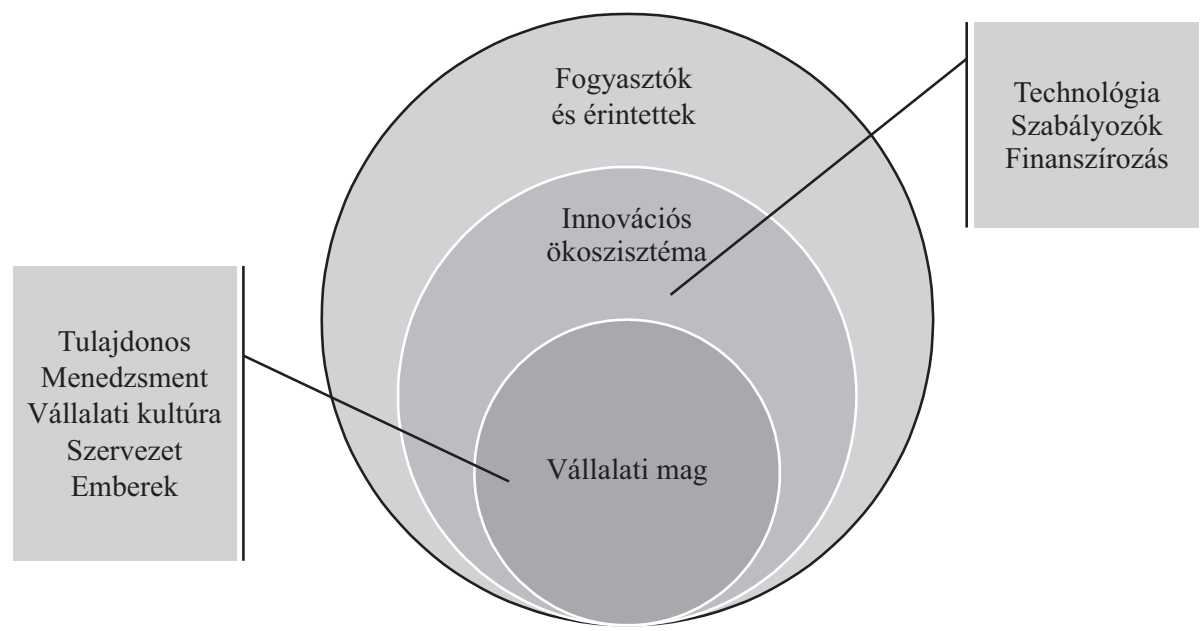

1. ábra. Az innovációs burok

(saját szerkesztés) 
A vállalati mag a technológiai ötletek üzleti termékké való átalakításának belső összetevőit foglalja magába. Mivel a schumpeteri teremtő rombolás hosszú távú elköteleződést kíván, kulcsszerepet kapnak a vállalati döntések fő befolyásolói, a tulajdonosi érdekek és a vállalatvezetői motivációk. A megújulást támogathatja, de az új ötleteket el is nyomhatja a válallati kultúra, ill. a vállalat szervezeti felépítése. Mindezek mellett kiemelkedő az alkalmazottak szerepe, hiszen ők a kreatív ötletek forrásai, és a rendkívül sok surlódással járó innovációs folyamat keresztülvivői.

A vállalati mag a vállalat körüli innovációs ökoszisztéma részeként müködik, és a beágyazottság mértékétől, valamint a az ökoszisztéma minőségétől függően támaszkodik annak szolgáltatásaira. Ezen ökoszisztéma részét képezik az alapvetö technológiai ötleteket szállító alapkutatások, illetve az azokat megvalósító szervezetek; a piaci és állami szabályozók; valamint a finanszírozási feltételeket biztosító infrastruktúra. A konkrét innovációs ötletek megszületése és üzleti versenyben való megméretése az üzleti-gazdasági környezet ösztönzői által befolyásolt. A magántulajdonban lévő szabad vállalkozásra és a versenyt kikényszerítő szabályozásra épülő kapitalista intézményrendszer nagy előnye, hogy nagyszámú üzleti-innovációs ötlet felbukkanására ösztönöz. De a tüzetesebb vizsgálat azt is megmutatja, hogy az ösztönző hatás függ a vállalatmérettől, a tulajdonosi szerkezettől (ezek az innovációs burok vállalati maghoz tartozó elemei) és a verseny konkrét szabályaitól (amelyek az innovációs ökoszisztéma részét képezik).

Az innovációs burok külső rétegét a fogyasztók és külső érintettek alkotják. Az innováció diffúziója, elterjedése, üzleti sikere függ a piac, a fogyasztók fogadókészségétől, és azoktól a szabályoktól, amelyek a piacra lépést alakítják. Bizonyos újítások elterjedése a társadalmi ellenállás miatt lassú, mások pedig azért késnek vagy nem jönnek létre, mert a szabályok nagyon erősen szürnek. Ez utóbbi mögött is gyakran a társadalom bizonytalansága áll. Amikor forradalmian új megoldások lehetősége villan fel, a szabályozási keretek egyre szigorúbbá tételével igyekszünk az újdonságok okozta bizonytalanságot, az esetleges negatív következményeket tompítani. Más esetekben egyszerủen csak arról van szó, hogy a szabályok változásának időszükséglete lényegesen meghaladja az üzleti újításokét, ezért állandó szabályozói lemaradásban vagyunk.

\section{KUTATÁS VAGY INNOVÁCIÓ?}

Bár az innovációs folyamat jelentőségét senki nem kérdőjelezi meg, a mérésére igen szerény eszközeink vannak. Leggyakrabban a kutatásra és fejlesztésre $(\mathrm{K}+\mathrm{F})$ fordított forrásokkal szokták jellemezni, bár ez messze nem azonos az innovációval. Az Oslói Kézikönyv szerint (OECD, 2005) „Az innováció új, vagy jelentősen javított termék (áru vagy szolgáltatás), vagy eljárás, új marketingmódszer, vagy 
új szervezési-szervezeti módszer bevezetése az üzleti gyakorlatban, munkahelyi szervezetben vagy a külső kapcsolatokban" (OECD, 2005, 46.). Ebben a definícióban a schumpeteri meghatározás köszön vissza.

Míg az innovációs aktivitás kiadásai, a fogalom tág határainak köszönhetően nehezen számszerüsíthetők, a K+F-kiadások statisztikai adatai egységes módszertan szerint állnak rendelkezésre, és így összevethetők. Az összehasonlítás leggyakrabban a GDP-arányos kiadások szerint történik, illetve ezzel szemléltethető a kiadások időbeli alakulása is. Az OECD-országokban a K+F-kiadások 1985 és 2015 között GDP-arányosan is növekedtek valamelyest, 2015-ben az OECD-átlag elérte a GDP 2,36 százalékát (OECD, 2018a). Ennek megfelelően a szabadalmak számában is növekedés tapasztalható, 142714 szabadalmat jelentettek be, amely a 2000-es értékhez képest 22,2 százalékos növekedést jelent (OECD.stat, 2019).

\section{AZ INNOVÁCIÓ TÍPUSAI}

Az innováció sokféleképpen mehet végbe, és ez a legfőbb oka annak, hogy mérésére nem fejlesztettek ki egységes módszertant. Megkülönböztetünk radikális és inkrementális innovációt:

- Az inkrementális innováció egy adott létező megoldás keretein belül történő fejlesztés.

- A radikális innováció azonban ennek a keretnek a megváltoztatására törekszik (Norman-Verganti, 2014).

A legtöbb innováció inkrementális, csak csekély mértékben hoz újat, ellenben biztonságos és költséghatékony. Ilyenkor például egy már meglévő termék továbbfejlesztése, tökéletesítése történik, a termék jobb minőségben, gyorsabban, olcsóbban stb. kerül a fogyasztókhoz. Jól megfigyelhető, hogy minél erősebb egy cég, és minél biztosabban ellenőrzi a piacait, annál inkább az inkrementális innováció irányába tolódik a fejlesztési stratégia fókusza. Ez pénzügyi szempontból kiszámíthatóbb, viszont a technológiai lehetőségek kibontakozása ezáltal lassul.

A radikális innovációnak számos akadálya van. Ilyen akadály például maga a vállalat, amely biztonságra és stabilitásra törekszik, ezért elvárja, hogy az új ötlet illeszkedjen a vállalat kompetenciáihoz, termékkínálatához, a gyártáshoz, a marketinghez és az elosztási csatornához. Az ötlet radikális jellegénél fogva nem talál megértésre a befektetők között, ráadásul számos esetben bizonyosodik be, hogy a jó ötlet sem feltétlenül talál pozitív visszhangra a fogyasztók részéröl. Összességében a radikális innovációs projekteknek csak egy elenyésző hányada sikeres, a kudarc esélye mintegy 96 százalék (Norman-Verganti, 2014).

Mindezen okok miatt sajátos kettősség figyelhető meg. Egyrészt az innovációs tevékenységet mérő statisztikák folyamatos fejlődést, gyorsulást sugallnak. 
Másrészt radikálisan új innovációra továbbra is nagyon ritkán kerül sor. Ez önmagában nem baj, csupán azt mutatja, hogy a technológiai lehetőségek valósággá válása igen lassú. A továbbiakban az innovációs burok elemeinek áttekintésével azt nézzük meg, hogy milyen tényezők lassíthatják az innovációs folyamatot.

\section{AZ INNOVÁCIÓS BUROK}

A vállalati mag olyan elemeket tartalmaz, amiket az innovátor közvetlenül befolyásolhat. Ugyanakkor a kialakult minták és üzleti modellek miatt már itt is érezhetők a társadalmi és gazdasági trendek.

- Tulajdonosi szerkezet: A vállalatméret és a külső tulajdonosok megjelenése miatt a vállalatok irányítása elválik a vállalatok tulajdonosi körétől. Az intézményi befektetők és az alacsony tulajdonosi hányadú, úgynevezett szórt tulajdonú tulajdonosok egyaránt pénzügyi befektetésként tekintenek a vállalatra, annak kiszámítható és stabil müködésében érdekeltek. E kiszámíthatóság része az, hogy a cég bevételei stabilan növekednek, a befektetett tőkére eső nyeresége előrelátható módon alakul, és ezért részvényeinek ára, illetve a tulajdonosoknak fizetett osztalék, vagyis a cég papírjaiba való befektetés hozama stabil. Emiatt nem érdekeltek a magas kockázatú és költséges fejlesztések megvalósításában.

- Menedzsment: A nagy vállalatméret a vállalati hierarchia növekedését is jelentheti, és nagyobb igényt az erősebben formalizált eljárások iránt. A vállalati stratégiát legjobban átlátó felsővezetők azok, akiknek innovátorként támogatniuk kellene a radikális újításokat a cégen belül. Ehhez ugyanakkor sok érdekük nekik sem füződik. Egyrészt a felsővezetők teljesítményét gyakran az éves beszámolók alapján ítélik meg, így a költséges projektek, amelyek célja egy radikálisan új ötlet piacra való bevezetése, azt a képzetet kelthetik, hogy a vezetők nem végzik kellő alapossággal és óvatossággal a munkájukat, vagyis le kell őket váltani. Az erős hierarchia ráadásul nehézzé is teszi az új projektötletek végigvitelét.

- Szervezeti megoldások: A felsővezetők óvatossága az ún. szűk keretezést (Thaler, 2016) megvalósító szervezeti megoldások elterjedéséhez vezet. A szűk keretezés legfőbb oka a túlzott kockázatkerülés és az erős jelen felé torzítás. A fejlesztési lehetőségek vállalaton belül való kezelésének bevett módszere az egyes projektek külön kezelése. Amikor a fejlesztési lehetöségek egyenként mind kockázatosak (a kudarc esélye megközelíti az 50\%-ot), de várható értékük pozitív, a szük keretezés miatt ezeket jellemzően senki nem meri felvállalni, holott sok ilyen projekt együttes megvalósítása a pozitív várható érték miatt hozzájárulna a vállalati érték és nyereségesség fokozásához. Az IL-KPMG közös felmérése (2018), amely 270 vállalatvezető 
megkérdezésén alapul, megmutatja, hogy a nagy cégek körében egyformán megfigyelhető a szük keretezés, és gyakori az innovációért felelős személyek körüli szervezeti bizonytalanság is.

- Vállalati kultúra ösztönzői: Az IL-KPMG felméréséből (2018) kiderül, hogy a megkérdezett vállalatvezetők a szervezeten belüli pozícióharcok mellett a kulturális problémákat tartják az innováció második legjelentősebb akadályozójának. A nagy, stabil piaci pozíciókkal bíró cégek kultúrájának része a kockázatvállalástól való tartózkodás, és a cégvezetők szerint a kultúra kifejezetten bünteti, stigmatizálja a kudarcokat. Minél nagyobb a szervezet, annál nagyobb kihívás a vállalkozói gondolkodás és kockázatvállalás ösztönzése a szervezetben. A vállalatok legtöbbjének nincs formális kompenzációs politikája az innovációra vonatkozóan, 35 százalékukban semmilyen ösztönzőt nem alkalmaznak.

- Alkalmazottak: Az innovációval kapcsolatos sikerek legalább annyira múlnak az emberi tényezőn, mint az erőforrások rendelkezésre állásán vagy a szabályozási rendszer minőségén (IBM, 2008). Az alkalmazottak viszonyulása fontos szerepet játszik az innováció sikerében. A munkavállalók elsősorban olyan innovációkkal szemben ellenségesek, amelyek az állásukat veszélyeztetik, nagy alkalmazkodási költségekkel járnak, vagy fokozzák a munkaterhelésüket, a fogyasztói elégedettséget fokozó újításokkal kevésbé ellenségesek (Zwick, 2000).

Az innovációs ökoszisztéma a vállalat környezetét alkotja, melynek formálásában a vállalatok akár aktív szerepet is vállalhatnak. Az ökoszisztéma vagy lánykori nevén a regionális innovációs rendszer (Cooke et al., 1998), a szakértők közmegegyezése szerint az innovációs folyamat alapvető befolyásolója (lásd például Schaeffer et al., 2018 összefoglalását).

- Technológia és kutatások: A technológiai lehetőségeket az alapkutatások és az ezekre épülő fejlesztéseket befogadó intézmények (egyetemek, kutatómühelyek) teremtik meg. Ezek müködését több megatrend befolyásolja. Az egyetemek finanszírozásában évtizedek óta tartó átrendeződés figyelhető meg, ami a legtöbb ilyen szervezet számára erős fenyegetést jelent. A finanszírozási bizonytalanság a nyugati társadalmakban negatív demográfiai trendekkel párosul. Az alapkutatás globális hálózatokon keresztül történő megvalósulása mellett erős koncentráció jelei is mutatkoznak. Napjaink egyik legfontosabb technológiai trendje az óriási adattömegek gépi megismerést használó algoritmusokon keresztül való feldolgozosának, az ún. Big Datának a térnyerése az alapkutatásokban (OECD, 2018b). Az ökoszisztémára gyakorolt hatása abban jelenik meg, hogy még koncentráltabbá teszi a tudás eloszlását, ezáltal sok térségben az innováció földrajzi akadályává válik. 
- Szabályozók: Az elavult szabályozási környezet lassítja az új eredmények begyürüzését. Számos példát látunk erre az oktatás és az egészségügy terén, ahol az erősen centralizált rendszerek akadályozzák az új eredmények létrejöttét és elterjedését. Széles körben ismert probléma továbbá az önvezető autók bevezetésének kérdése, ahol a nyilvánvaló előnyök ellenére az érdekcsoportok ellenállása és a jogszabályi és felelősségi kérdések tisztázatlansága miatt évekig elhúzódhat a bevezetés és elterjedés (Litman, 2018). A szabályozási rendszer természetes igényeink miatt válik egyre komplexebbé. A kiszámíthatóságot a szabályok rendszerével igyekszünk fokozni. Ez rövid távon kényelmet biztosít, de hosszabb távon gyengítheti a radikális innovációt. Egyes technológiák, például a mesterséges intelligencia esetén ugyanakkor különösen fontos lehet a fejlesztés sarokköveinek előzetes lefektetése (Tegmark, 2017).

- Finanszirozás: A K+F és innováció támogatása terén megváltoztak a prioritások. A növekedésen és munkahelyteremtésen túlmutató globális és társadalmi kihívások megválaszolása, a felgyorsult és bizonytalanná vált technológiai változások és az ezek nyomán keletkező biztonsági kockázatok kezelése új feladatokat teremtenek. Ilyen az adatokhoz való hozzáférés biztosítása és az adatmegosztás, az innováció szereplői közötti együttmüködés ösztönzése és általában a nyitott innováció elősegítése, a verseny és a szellemi tulajdonjogok kereteinek biztosítása (OECD, 2018b).

Az innovációs burok külső rétegét a fogyasztók és érintettek képezik. Az új termék vagy szolgáltatás forgalomba hozatala döntő fontosságú az innovációs folyamatban. Főként radikális újítások esetén kérdéses, hogy a fogyasztók megértik-e, elfogadják-e az új terméket vagy szolgáltatást. A változásokkal összefüggő ellenállás természetes része az emberi viselkedésnek. Az ellenállás mértékét fogyasztóspecifikus (mint a személyiség, az attitüdök, korábbi tapasztalatok) és innovációs jellemzők (kompatibilitás, kockázat) egyaránt befolyásolják (Ram, 1987). Az olyan újításoknak, amelyek rövid távon költségeket rónak a fogyasztókra, és előnyük csak hosszabb távon jelentkezik, nem túl sok esélyük van a piacon.

\section{KÖVETKEZTETÉSEK}

A technológiai lehetőségek az innovációs folyamaton keresztül válnak életünk részévé, és járulnak ezáltal hozzá a társadalmi-gazdasági környezetünk átalakulásához. Bár azt várjuk, hogy ez a környezet az elkövetkező évtizedekben gyökeresen megváltozik, az innovációs folyamat egyes befolyásolói ezt a várakozásunkat meghazudtolhatják. Miközben egyre többet költünk kutatásra és fejlesztésre, növekszik a bejelentett szabadalmak száma, úgy tűnik, hogy ez a felfutás főleg az inkrementális innovációra jellemző. Az inkrementális innovációk esetén a vál- 
tozás nagyon lassú, fokozatosan vezet be olyan megoldásokat, amelyek egy kicsit jobbak, szebbek, hatékonyabbak, vonzóbbak stb. a korábbiaknál. Ha az elkövetkező száz évben csak inkrementális innovációra kerülne sor, az innovációs folyamat egészen biztosan nem vezetne a Yuval Noah Harari által vizionált gyökeres átalakuláshoz.

Felforgató hatása a radikális innovációnak van. A radikális innovációt ugyanakkor több társadalmi-gazdasági intézmény is hátráltatja. Ilyen a szétaprózódó tulajdonosi szerkezet, a növekvő vállalatméret és vállalati hierarchia, illetve a pénzügyi befektetői szemlélet által korlátok közt tartott vállalatvezetők. Az innovációs ökoszisztéma egyes elemei szintén akadályokat támaszthatnak. A kutatások globalizálódása, koncentrálódása sok régióból kiszakíthatja az alapkutatásokat. A társadalmi-gazdasági szabályok, miközben kiszámíthatóbbá teszik a környezetünket, és egyes területeken nagy szükség lenne a globális elköteleződésre, nagyon költségessé és hosszúvá teszik a radikális innovációt. A finanszírozási infrastruktúra elégtelenségei ugyancsak visszafogó erőt képviselhetnek. Végül a társadalom értékrendje, a változásokkal való szembenállás ugyancsak hátráltató tényező.

A kutatást az EFOP-3.6.2-16-2017-00007 azonosító számú, „Az intelligens, fenntartható és inkluzív társadalom fejlesztésének aspektusai: társadalmi, technológiai, innovációs hálózatok a foglalkoztatásban és a digitális gazdaságban" című projekt támogatta. A projekt az Európai Unió támogatásával, az Európai Szociális Alap és Magyarország költségvetése társfinanszírozásában valósul meg.

IRODALOM

Bartha Z. - S. Gubik A. (2018): Oktatási kihívások a technikai forradalom tükrében. Észak-magyarországi Stratégiai Füzetek, 15, 1, 15-29. https:/www.researchgate.net/publication/324475382_ Oktatasi_kihivasok_a_technikai_forradalom_tukreben

Cooke, P. - Uranga, M. - Etxebarria, G. (1998): Regional Systems of Innovation: An Evolutionary Perspective. Environment and Planning, 30, 9, 1563-1584. https://pdfs.semanticscholar. org/920d/4024752438c701eblbda26da0545cc0359e6.pdf

Greenwood, J. - Seshadri, A. - Yorukoglu, Y (2005): Engines of Liberation. The Review of Economic Studies, 72, 1, 109-133. DOI: 10.1111/0034-6527.00326, http://www.jeremygreenwood. net/papers/engines.pdf

Harari, Y. N. (2018): 21 Lessons for the $21^{\text {st }}$ Century. New York: Spiegel \& Grau

IBM (2008): The Enterprise of the Future. Life Sciences Industry Edition. IBM GLOBAL CEO STUDY

IL-KPMG (2018): Benchmarking Innovation Impact 2018. https://info.kpmg.us/content/dam/info/ en/innovation-enterprise-solutions/pdf/2018/benchmarking-innovation-impact-2018.pdf

Litman, T. (2018): Autonomous Vehicle Implementation Predictions Implications for Transport Planning. Victoria Transport Policy Institute, https://www.vtpi.org/avip.pdf 
Norman, D. A. - Verganti, R. (2014): Incremental and Radical Innovation: Design Research Versus Technology and Meaning Change. Design Issues, 30, 1, 78-96. https://www.researchgate.net/ publication/264595739_Incremental_and_Radical_Innovation_Design_Research_vs_Technology_and_Meaning_Change

OECD (2005): Oslo Manual, Guidelines for Collecting and Interpreting Innovation Data. A joint publication of OECD and Eurostat. DOI: 10.1787/19900414, https://www.oecd-ilibrary.org/science-and-technology/oslo-manual_9789264013100-en

OECD (2018a): Gross Domestic Spending on R\&D (Indicator). DOI: 10.1787/d8b068b4-en, https:// www.oecd-ilibrary.org/industry-and-services/gross-domestic-spending-on-r-d/indicator/english d8b068b4-en

OECD (2018b): OECD Science, Technology and Innovation Outlook 2018 Adapting to Technological and Societal Disruption. Paris: OECD Publishing. DOI: 10.1787/sti_in_outlook-2018-en, https://www.oecd.org/sti/oecd-science-technology-and-innovation-outlook-25186167.htm

OECD.stat (2019): Patents by Technology (Statistics). https://stats.oecd.org/Index.aspx?DataSetCode $=$ PATS IPC

Ram, S. (1987): A Model of Innovation Resistance. Advances in Consumer Research, 14, 4, $208-$ 213. http://www.acrwebsite.org/volumes/6688/volumes/v14/NA-14

Schaeffer, R. P. - Fischer, B. - Queiroz, S. (2018): Beyond Education: The Role of Research Universities in Innovation Ecosystems. Foresight and STI Governance, 12, 2, 50-61. DOI: 10.17323/2500-2597.2018.2.50.61, https:/www.researchgate.net/publication/326226154_Beyond_Education_The_Role_of_Research_Universities_in_Innovation_Ecosystems

Shawn, R. (2018): 2018 TIBCO CXO Innovation Survey. https://www.apexofinnovation. com/2018-tibco-cxo-innovation-survey/

Stoneman, P. (1995): The Handbook of Economics of Innovation and Technological Change. Cambridge, MA: Blackwell

Tegmark, M. (2017): Life 3.0: Being Human in the Age of Artificial Intelligence. New York: Penguin Random House LLC

Thaler, R. H. (2016): Rendbontók. A viselkedési közgazdaságtan térnyerése. Budapest: HVG Könyvek

Zwick, T. (2000): Empirical Determinants of Employee Resistance against Innovations. Mannheim, Germany: Centre for European Economic Research (ZEW), ftp://ftp.zew.de/pub/zewdocs/dp/dp0047.pdf 